\title{
An Investigation of How Online Learning Reduces ZPD in Mandarin Language Classrooms
}

\author{
Noor Hanim Rahmat ${ }^{1, *}$, Mok Soon Sim ${ }^{1}$, Lau Suk Khin ${ }^{1} \&$ Ling Tek Soon ${ }^{2}$ \\ ${ }^{1}$ Akademi Pengajian Bahasa, Universiti Teknologi MARA, Malaysia \\ ${ }^{2}$ Institute of Chinese Studies, University of Malaya, Malaysia \\ *Corresponding author: Akademi Pengajian Bahasa, Universiti Teknologi MARA, Malaysia. \\ E-mail: noorh763@uitm.edu.my
}

Received: January 22, 2021 Accepted: March 3, 2021 Published: March 10, 2021

doi:10.5296/ije.v13i1.18399 URL: https://doi.org/10.5296/ije.v13i1.18399

\begin{abstract}
Traditionally, language needs to be learnt face-to-face. Pronunciation practices, role play, group discussions are all activities that allow interaction among learners. Previously, some things are better learnt face-to-face, while some can be learnt online. Nevertheless, the pandemic has accelerated the need for online learning in almost all courses offered at institutions. Devices used for online learning can be used as a leaning tool by learners to improve understanding. These devices help to reduce a learner's zone of proximal development (ZPD) thus maximizing learning. Online learning has been said to facilitate rather than hinder language learning. This study is therefore done to explore how it helps the learning of Mandarin. The study investigates how online interaction affects the learning of Mandarin in language classrooms. 173 participants responded to a 28 items (5 likert scale) instrument. Findings reveal how online learning influences interaction, encourages participation of more knowledgeable others, and improves interaction with content among learners.
\end{abstract}

Keywords: online learning, Mandarin, zone of proximal development, interaction, more knowledgeable others 


\section{Introduction}

\subsection{Background of Study}

Due to impact of Covid-19 Pandemic, many teachers and students in Malaysia and around the world are relocating some aspects of education online. According to Gao (2020), virtual classes has become the new norm. Nevertheless, this transformation causes new defiance to some fields of study such as the foreign language teaching. Previously, many felt that only face-to-face interactions are suitable for foreign language learning. The discipline of teaching Chinese as a foreign language (CFL) is among the many affected by the pandemic. Due to the urgent demand, most of CFL programs rapidly developed face-to-face classes online throughout the world. This unanticipated scenario added difficulties of teaching and learning CFL which had already existed in face-to-face classroom.

As such, foreign language instructors are constantly coming up with new ways to teach the language via online. According to Yang, Yin \& Wang (2018), some teachers shifted their Chinese as a foreign language online. Their study explored the influence of using flipped classroom to teach Chinese as a foreign language at the elementary level. Students gave higher mean gradings on three characteristics of their learning experience: level of required self-determination, amount of exercise in class, and inspiration of interest in the subject. Another research was conducted by Yi, Xu, Mursitama \& Yetty (2017) and they looked into leaners' reaction towards mobile learning based for the learning of Mandarin as a foreign language. Findings revealed that the obstacle of students is to compose a sentence based on vocabularies learned.

\subsection{Statement of Problem, Objective and Research Questions}

In a study by Lewis, Paul, Simons and Fennig (2015), the Chinese language family is the biggest language family worldwide with about 1,197,000,000 speakers. Lewis et al. (2015) reported that the Chinese language family is divided into thirteen groups and the Mandarin Chinese group is the biggest with 848 million native speakers. Besides, Mandarin is one of four official languages of the Republic of Singapore and one of six official languages of the United Nations. Therefore, Mandarin plays a role as an effective communication tool with these governments on different levels. Moreover, based on the International Monetary Fund (2015) China is the biggest economy in the world as of April 2015 in regards to adjusted purchasing power parity and second in the world, the United States is the first, when regarding raw economic power. In lieu of that, more learners are making Mandarin as their choice of additional language. Many has taken the steps to include this popular language in their learning plan (Moloney \& Xu, 2015; Wang \& Curdt-Christiansen, 2016; Zheng \& Gao, 2016 \& Hanban, 2017). The study by Chua and Azlan (2019) identified factors that motivate learners to keep learning Mandarin. Campbell and Storch (2011) and Dörnyei's (2005, 2009) disclosed that non-native Mandarin learners were motivated to keep learning Mandarin because they are aware of the importance of Mandarin in the view of employability, self-interest and raising Mandarin mark. According to Halliday (2014), there has been reasonable debate over "how to teach Chinese to foreign learners". He investigated the usual issues which Chinese teachers encountered in teaching Chinese to the speakers of English. In 
addition to that, Ma, Gong, Gao, Xiang (2017) found that there are differences between Mandarin learning ability even among Chinese of different heritage.

Many would agree that learning Mandarin is not an easy task. Mandarin is a tonal language and standard Mandarin has four tones. Chinese is also viewed as a logographic writing system because its written symbols (characters) symbolize lexical morphemes rather than individual phonemes (Perfetti and Dunlap 2008). Hanyu Pinyin is used to spell syllables for Chinese characters, and complete syllables include initials, finals and tone marks. Zhang (1992), and Shen and Jiang (2013) felt that the need to teach a variety of characters and tone marks made it difficult to teach Mandarin online.

There were some studies on the teaching and learning of Mandarin language in the Malaysian context. The study by Chua, Tan and Lin (2015); Mok, Lau and Sankaran (2019) and also Rahmat, Mok, Lau and Fan (2020) felt that the learners need more time to learn the Chinese characters and this need can be addressed through technology. According to Ma, Gong, Gao, and Xiang (2017) and Maloney and Xu (2015), there should be more empirical studies which can enlighten the growth and application of new pedagogical inventiveness and exercises (Jiang, 2012).

Generally, this study is done to explore the perception of learners on learning Mandarin online. It is hoped that the findings will furnish answers to the questions below.

1.1.1 How does interaction influence online learning among learners of Mandarin?

1.1.2 What influence does knowledgeable others have on leaners of Mandarin online

1.1.3 How does online learning influence Learner-to-content (technology and tools) engagement?

\section{Literature Review}

\subsection{Introduction}

This segment examines issues of learners' strategies for learning Mandarin, the disadvantages and advantages of online learning. Online learning platforms can bring more good than harm to language learners. Its use can help to reduce the zone of proximal development as online interaction can facilitate interaction among learners.

\subsection{Learners' Strategies for Learning Mandarin /Models for Learning Mandarin}

There are reportedly many learning strategies for learning Mandarin. Wu (2007) and Wang (2013) added that learners needed strategies facilitate their learning. However, sometimes, learners display their absence of responsiveness to Chinese characters (Chen \& Li, 2015) and more strategies are used to overcome this. Good learners are able to manage exceptionally their own learning (Oxford, 1999) and this facilitates language learning. Sung (2014) found that participants who were noted to repeatedly use special phonological strategies performed better on the phonological comprehension part of the test and the ones who noted repeatedly using orthographic strategies performed better on the graphic comprehension, graphic 
production, and phonological production parts of the test.

Lew (2019) suggested four steps to enhance learning. Firstly, teachers should build a joyful and casual learning setting. Steve Kaufmann (2003) suggested that the learning of Mandarin is done in a relaxed environment. They can invent more chances for them to interact with native speakers (Cornell, $2002 \&$ McDermontt, 1977). Secondly, teachers should encourage learners to have at least one consistent Mandarin learning collaborator. Even though interacting with native speakers is the quickest manner to improve Mandarin mastery; however, due to the cultural environment, learners may sometimes not encounter Chinese persons in their own location. In this case, teachers need to propose Mandarin learning strategies to learners. In order to master Mandarin well, learners need to learn to collect more language input outside the classroom and look for more chances to use the language. Thus, teachers have the responsibility to help young learners, propose more learning strategies to learners intentionally, and lead learners to find and adopt their own learning approaches.

\subsection{Disadvantages and Advantages of Learning Mandarin Online}

Like all types of learning, there are many disadvantages as well as advantages of learning Mandarin online.

\subsubsection{Disadvantages}

There are some reported challenges for the teaching-learning of Mandarin online. Gao (2020) found that learners' perceived dilemma of learning characters in online delivery as different from those reported in a face-to-face mode of learning. They sensed that threats like technological and physical obstacles (e.g., internet issues and learning space) and requests for self-discipline and time arrangement capabilities, can in turn influence the learners' mental health and may need encouragement for learning. Thus, most of the learners accepted that repeated exercise in the use of different materials equipped was successful in growing their character writing and reading skills.

In a traditional Mandarin learning class, students will be able to gain peers' attention and be able to learn with companions of the same level. Some might see it as a competition between their own colleagues to learn faster, thus making it more fun. But this is not happened in online class. Another disadvantage is students who learn online are unable to ask for assistance as most online courses are videos. They may take more time to have to research the answer to their question, and there is even no guarantee that it is right unless they have communicated with the instructor. In addition to that, Loeb (2020) felt that in the online environment, some learners may face obstacles that can hinder their learning. This, again, can decrease their motivation to learn online.

\subsubsection{Advantages}

Online learning courses are sometimes preferred because they are more advantageous than conventional face to face courses. Learners can plan their online lessons around their current duties and dedications. They refer to the multimedia content and learning resources at whatever time most suitable to them. They do not need to move- they can merely log in to the 
virtual campus from the comfort of their own homes or offices. Besides, online learning is cheaper than conventional courses.

Online courses also allow learners to have full control to their own learning as learners can study at their own pace. It is believed that learners take in more knowledge when they learn at their own pace. It is also believed that learners are able to absorb knowledge faster when they do it at their own pace. Online learning is definitely the more productive choice for learners.

Zhang (2020) and Lyu and Qi (2020) reported that there are many advantages of utilizing digital tools for teaching Mandarin language online. His study reported six advantages: (a) improves teaching effectiveness, (b) improves teaching quality; (c) increases learners' learning encouragement and passion; (d) introduces digital teaching tools (Google Docs, audio/video, social media, etc.) into online teaching; (e) supplies for a variety of learning modes and requirements; and also (f) establishes new chances for language evaluation.

\subsection{ZPD (Zone of Proximal development) in Language Learning}

Leaners are said to learn better among their peers. This type of learning mirrors social constructivism. This type of learning can also be done online especially when learners gain knowledge through zone of proximal development (zpd) and scaffolding.

\subsubsection{Social Constructivism}

According to McLeod (2018), in Vygotsky's social constructivism, knowledge is co-constructed and that individuals learn from one another. Learners must be involved in the learning process. Learning occurs with the assistance of other people, therefore creating the social view of the theory. Based on Figure 1, learning process takes place because learning is constructed through interaction. Learning also occurs with the assistance of other people around the learner.

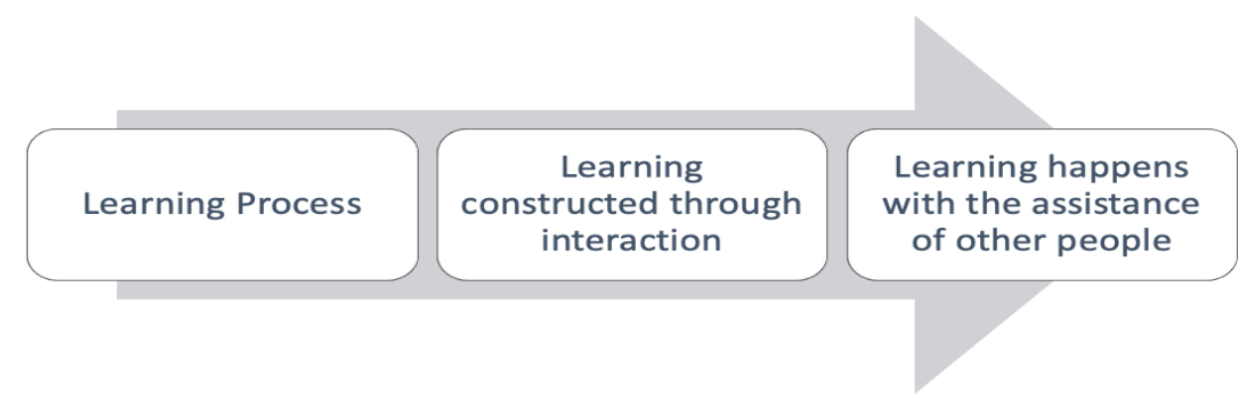

Figure 1. Social Constructivism (source: McLeod (208)

\subsubsection{ZPD and Scaffolding}

Figure 2 presents how learning takes place through zpd and scaffolding. According to McLeod (2018), the inner circle (Figure 2) shows what the learner can achieve when he /she is on his/her own. The outer circle represents what he/she can learn from peers. This circle can be further enhanced through interaction with knowledgeable others and also through the 
use of technology and tools.

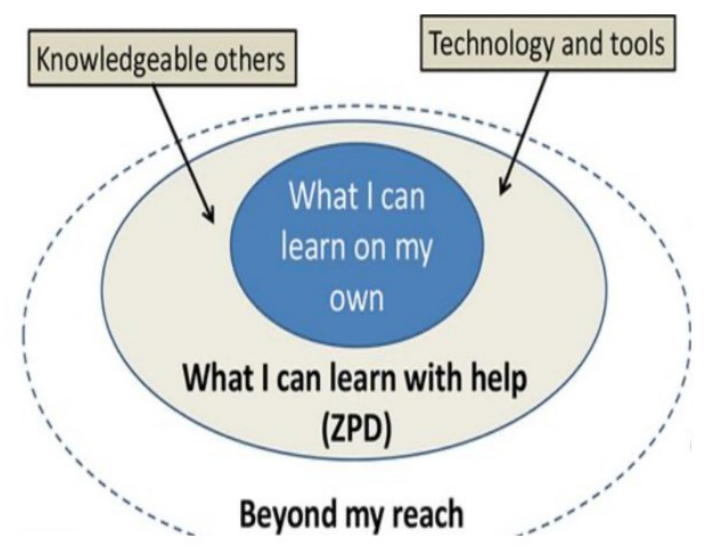

Figure 2. ZPD and Scaffolding (Source: McLeod 2018)

\subsection{Shifting to Online Learning}

The current world situation has pushed the authorities to make learning available online. According to Dickson (2015) and Jureynolds \& Ying (2014), many institutions have joined the bandwagon of online learning by providing quality online course management. However, some fear learners lose the ability to engage during online sessions. The definition of engagement can further be redefined to mean more than just face-to-face interactions. Kuh (2003) views engagement as "the time and energy students devote to educationally sound activities" (p. 25). There are five clusters of activities showing student engagement This includes (a) overcoming the level of academic obstacle, (b) being in an encouraging campus environment, (c)participating in enhancing educational experiences, (d) joining in learnerfaculty communication, and (e) cooperating in dynamic and interactive learning (Robinson \& Hullinger, 2008).

Figure 3 presents Moore (1993) identification of three types of interaction are inherent in productive online courses. They are (1) learner-to-learner interaction, (2) learner-to-instructor interaction, and (3) learner-to-content interaction. Lear et al. (2010) revealed that interactions with collaborators, instructors, and content help online learners become active and more engaged in their courses.

\section{Learner}

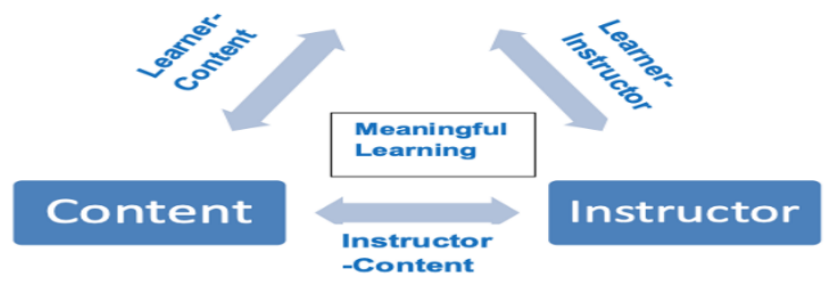

Figure 3. Meaningful Online Learning (Source: Moore, 1997) 


\subsection{Past Studies}

Online learning may include learning using gadgets and the learning can have numerous impacts on the learners. A study on the learning Mandarin using smartphones was conducted by Abdullah, Ahmad Tajuddin, and Goh (2019). The researchers looked at how smartphones influence positively students' language performance, task accomplishments, and personal study. A set of questionnaire was distributed to 79 undergraduates from a public university. The statistics indicate that all the respondents agreed that learning Mandarin via smartphones has affected their language performance; task accomplishment and personal study positively. Next, the study by Falloon (2011) surveyed the use of the Web-based virtual environment, Adobe Connect Pro, in a postgraduate online teacher education programme. The study applied the tenets of Moore's Theory of Transactional Distance (Moore, 1997) to investigate the effectiveness of using the virtual classroom to develop quality dialogue. It also studied how both internal and external structural elements are associated to the reason and use of the classroom.

Online learning influence learners' engagement in many ways. Martin \& Bolliger (2018) looked into the influence of online learning on learners. The study found that learner-to-learner, learner-to-instructor, and learner-to-content engagement strategies were used in online learning. This survey-based research explored learner's acknowledgement on various engagement strategies used in online courses based on Moore's (1997) interaction framework. 155 learners answered a 38-item survey on learner-to-learner, learner-to-instructor, and learner-to-content engagement strategies. Findings revealed that some learners reflected that online discussions were the least useful strategy. This finding challenged other results that exhibited discussions that deepen students' understanding of content. Nevertheless, respondents indicated that structured discussions with guiding questions and/or prompts are more valuable than unstructured discussions.

Different types of learners are affected by online learning in different ways. Zhao, Blankinship, Duan, Huang, Sun, Bak (2020) reported a study comparing teaching written and spoken Chinese individually to adult learners who had no prior proficiency of Chinese in the traditional classroom background and in the online setting. This study investigated the challenges and limitations of teaching Chinese as a foreign language. Students' experience of both components of course (written and spoken) was positive. Nevertheless, students who experienced classroom teaching first and then switched to online delivery observed the online setting as a good substitution. On the other hand, Tseng, Lin, and Chen (2018) reported that online kindergarten to twelfth grade (K-12) language learners perceived to have negative insight of their learning. This study investigated a 12-day immersive online high-school Chinese-language course that comprised daily synchronous sessions and interactive technology-enhanced assignments. The study also looked at how students engaged in meaningful social interactions. Based on the inspection of the 35 participants' survey responses and their language presentation, respondents reported positive experience of the course.

Finally, Xu, Li, \& Li (2019) examined the efficacy of an online application in assisting 
beginning-level Chinese learners to enhance their knowledge of the tones in Mandarin Chinese. Two groups-one experimental and one traditional—of beginning Chinese learners from two universities in the Midwest took part in this research. The experimental group $(n=20)$ used the online application in 15-minute sessions in class. The traditional group $(n=11)$ participated in traditional instructor-led practice in class. Both groups completed a pre-test, an immediately administered post-test, and a delayed post-test designed to assess their knowledge of the tones of monosyllabic and disyllabic words. No statistically notable contrast was found between the two groups in their tone knowledge performance in the post-test and in the delayed post-test. However, the experimental group showed a positive trend in enhancing their knowledge on those tones with the guidance from the instructors.

\subsection{Theoretical Framework of the Study}

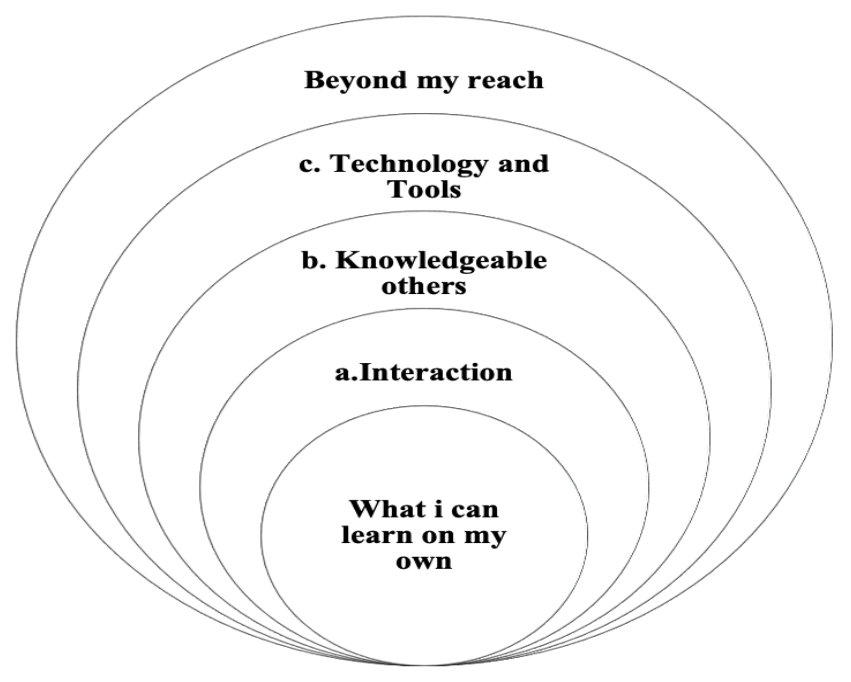

Figure 4. Theoretical Framework of the Study

The theoretical framework is rooted from Moore's (1997) model for online learning engagement and McLeod's (2018) interpretation of Vygotsky's zone of proximal development and scaffolding in learning. Based on the theory of zone of zone of proximal (zpd) development is the sone between what the learner can learn on his/her own and what is beyond his/her reach. Zpd can be reduced through the learners' interaction, communication with knowledgeable others and also through the use of technology and tools. This zpd can be reduced with the implementation of online learning (technology and tools) for learners of Mandarin language. According to Moore (1997), online learning enables leaners to learn through (a) learner-to-learner (interaction), (b) learner-to-instructor (knowledgeable others) and (c)learner-to-content (technology and tools) interaction.

\section{Method}

This quantitative study is done to investigate how online learning can influence learners' 


\section{Macrothink}

interaction with their peers and content. 173 respondents were randomly chosen to respond to a 28-items using 5-likert scale. Reliability analysis (Cronbach's Alpha) in table 1 of the instrument revealed a score of 0.960 thus showing a high reliability. Data is collected via online on goggle form. Data analysis is done suing SPSS version 26 to reveal the frequency of responses in the form of mean scores. Findings is presented based on the research questions in the form of bar charts.

Table 1. Cronbach Alpha

\begin{tabular}{cc}
\hline $\begin{array}{c}\text { Reliability } \\
\text { Cronbach's Alpha }\end{array}$ & $\begin{array}{c}\text { Statistics } \\
\text { N of Items }\end{array}$ \\
\hline .960 & 28 \\
\hline
\end{tabular}

\section{Results}

\subsection{This Section Presents Findings Based on the 3 Research Questions (RQ)}

(a) How does interaction influence online learning among learners learning Mandarin? (in 4.2)

(b) What influence does knowledgeable others have on leaners learning Mandarin online (in 4.3)

(c) How does online learning influence Learner-to-content (technology and tools) engagement? (in 4.4)

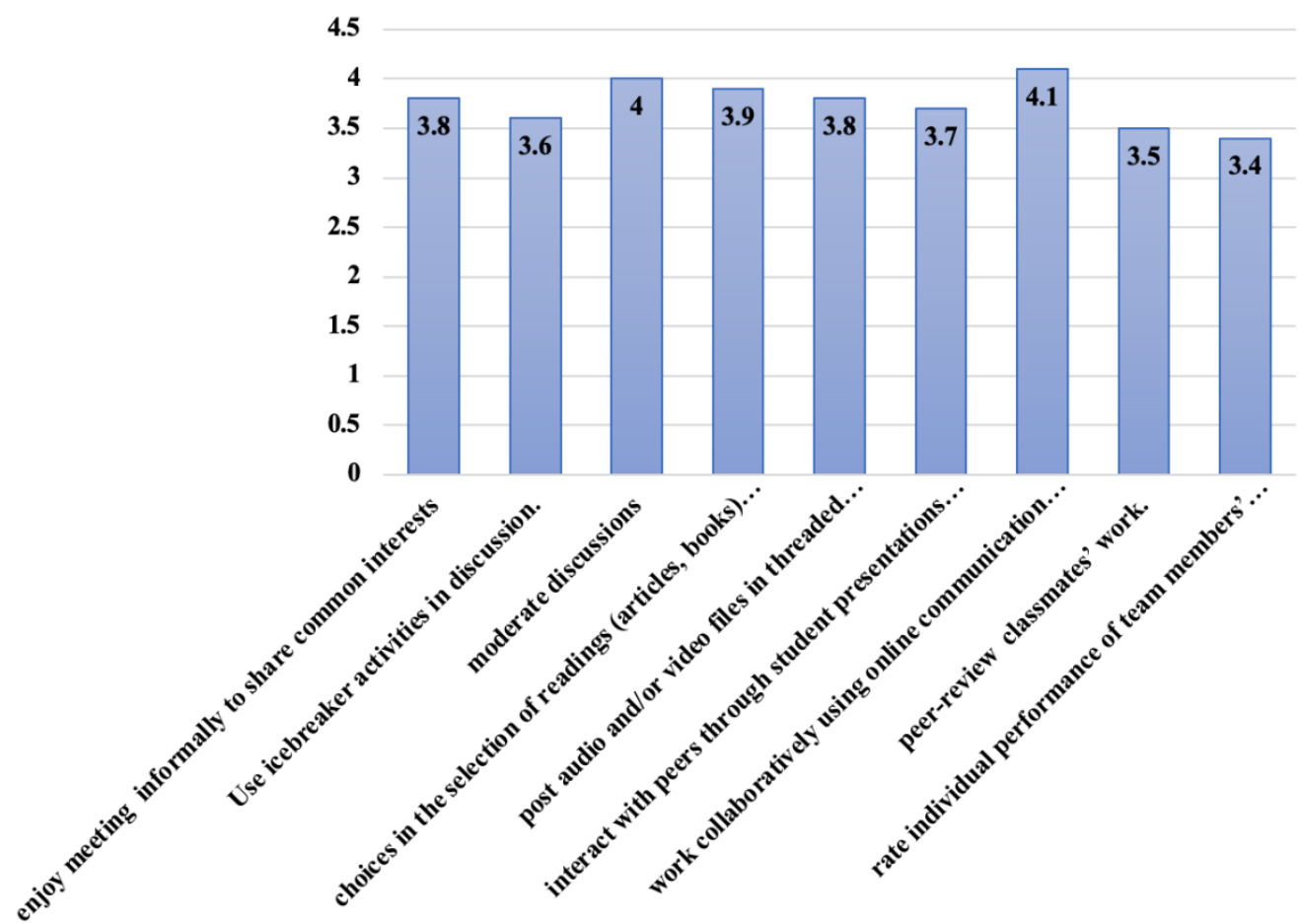

Figure 5. Mean Score for Interaction 


\section{Macrothink}

\subsection{Interaction}

This section reports findings for RQ1mentioned above.

Figure 5 shows the frequency for learner interaction in terms of mean scores. The highest mean is reported for "Work in groups" (4.1). Students also reported that they found it useful to have "Moderate discussions" (4.0), a "variety of reading materials online" (3.9), and also "meet informally and post video" (3.8)

\subsection{Knowledgeable Others}

This section reports findings to answer RQ 2 above.

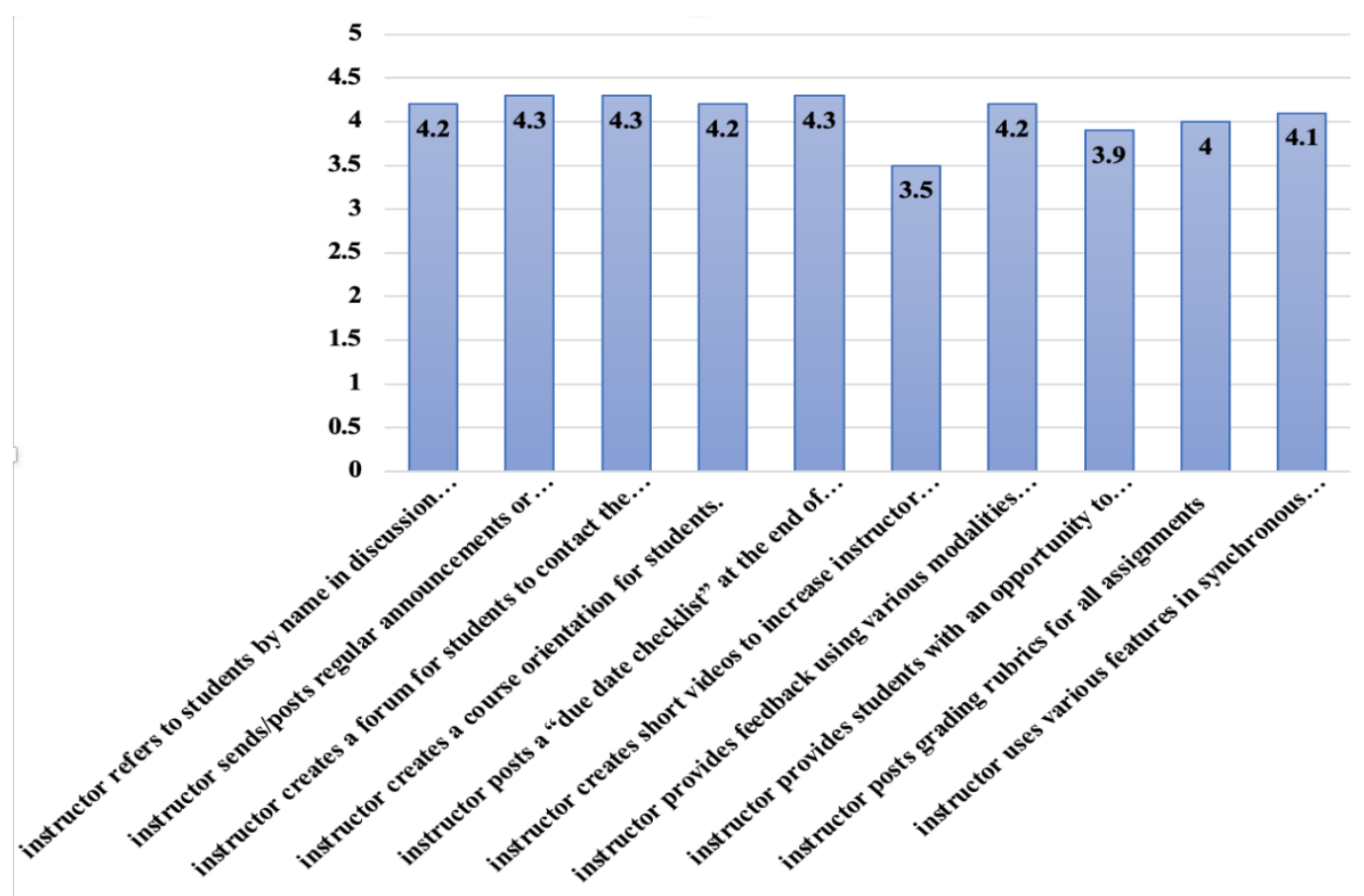

Figure 6. Mean Score for Knowledgeable Others

Figure 6 shows the frequency for knowledge others in terms of mean scores. Learners found it useful if the instructor to "post due-date checklist" (4.3), "post regular announcements" (4.3), and also create forum (4.3). They also liked that the instructor "referred to students by name" (4.2), created "course orientation for students" (4.2), and also "provided feedback using various modalities" (4.2).

\subsection{Technology and Tool}

This section presents findings to answer RQ 3 mentioned above. 


\section{$\Delta$ Macrothink}

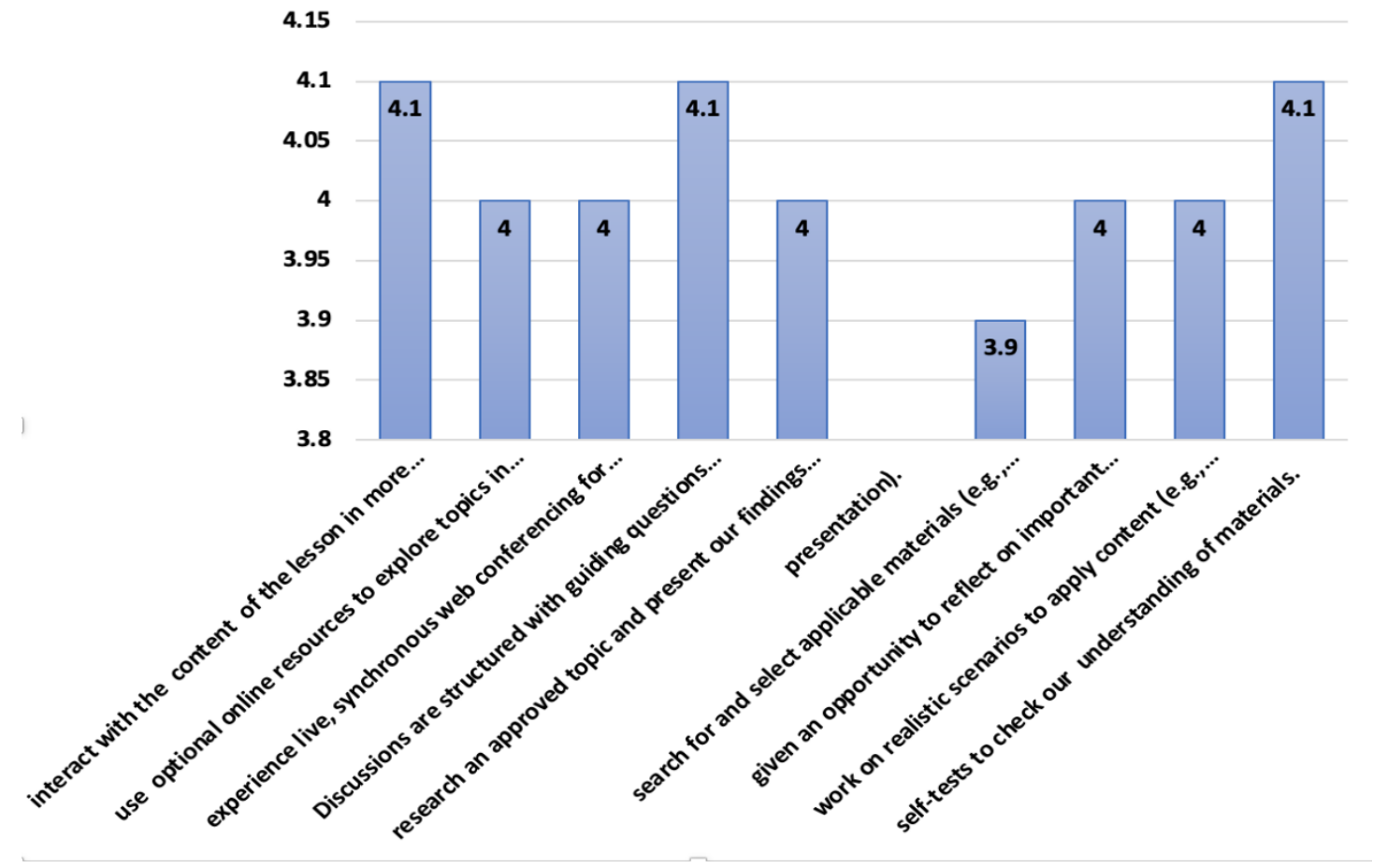

Figure 7. Mean Score for Technology and Tool

Figure 7 presents the frequency for technology and tool in terms of mean score. Findings reveal that the learners preferred "interaction with content" (4.1), to "have discussion that is guided with guiding questions" (4.1), to do "self-check for understanding of materials" (4.1), use "optional online resources" (4), gain "experience that is live, synchronous" (4), gain "approval of topic" (4), be "given the opportunity to reflect on important elements" (4), and also "work on realistic scenarios" (4).

\section{Conclusion}

\subsection{Summary of Findings and Discussion}

Findings reveal that the learners appreciated the opportunity to interact in many ways. The interactions encouraged more discussions among them thus enabling more meaningful interactions. Martin \& Bolliger (2018) also agreed that interactions helped deepen students' understanding of the content. However, they suggested structured rather than unstructured discussions.

More knowledgeable others refer to both peers and their instructors. The presence of more knowledgeable others sometimes come in the form post-formal learning environment. Learners are given the opportunity to communicate in a more informal setting. Interaction with a more knowledgeable other can allow learners to learn more than he /she already knows. $\mathrm{Xu}$, Li \& Li (2019) felt that more knowledgeable others allow learners to practice their pronunciation skills in a less threatening environment for the learners. 
Interestingly, findings reveal that although learners are positive towards online learning, they preferred to have some form of interaction with the content. The study by $\mathrm{Yi}, \mathrm{Xu} \&$ Yetty (2017) as well as Goh (2019) found that learners were positive towards using mobile devices. However, Gao (2020) reminded instructors to be careful with online learning as technology and physical barriers can also be a hindrance for online learning.

\subsection{Pedagogical Implications}

To teach Mandarin online efficiently, first the teacher should choose the most suitable platform for all the students. Accessibility are applicability are among the factors which need to be taken into consideration when the teachers choose the learning platform. In the design of content delivery, the teachers are encouraged to make it interesting and interactive, such as provide some online games. Besides, teachers also need to give the chance to their students to collaborate with their peers through Mandarin online activities.

\subsection{Suggestions for Future Research}

The future research can focus on addressing issues associated with students' ICT literacy enhancement, the application of technology for achieving utmost Mandarin online learning effect and students' self-directed learning. It is vital to explore the relationship between ICT and Mandarin class project design so as to deliver constructive teaching tasks and deal with how to enhance Mandarin teachers' consciousness and capability about integrating ICT into their instruction.

\section{References}

Abdullah, N. A. C., Ahmad Tajuddin, A. J., \& Goh, Y. S. (2019). Mandarin Students' Perceptions of Smartphone Applications in Mandarin Learning. Universal Journal of Educational Research, 7(9A), 61-70.

Chua, H. W., \& Azlan, M. A. K. (2019). Factors influencing foreign language learners' motivation in continuing to learn Mandarin. Journal of Social Science, 5, 1-6. https://doi.org/10.37134/ejoss.vol5.1.1.2019

Campbell, E., \& Storch, N. (2011). The changing face of motivation a study of second language learners' motivation over time. Australian Review of Applied Linguistics, 34(2), 166-192. https://doi.org/10.1075/aral.34.2.03cam

Chua, H. W., Tan, T. G., \& Lin, C.Y. (2015). A review of challenges in learning Chinese characters among non- native learners in Malaysia. Indian Journal of Arts, 5(16), 93-100.

Dixson, M. D. (2015). Measuring Student Engagement in the Online Course: The Online Student Engagement Scale (OSE). Online Learning, 19(4), 1-15.

Dörnyei, Z. (2005). The psychology of the language learner. Mahwah, New Jersey: Lawrence Erlbaum Associates. 
Dörnyei, Z. (2009). The L2 motivational self-system. In Z. Dörnyei, \& E. Ushioda, (Eds.), Motivation, language identity and the L2 self. Bristol: Multilingual Matters, 9-42.

Falloon, G. (2011). Making the Connection: Moore's Theory of Transactional Distance and its Relevance to the Use of a Virtual Classroom in Postgraduate Online Teacher Education. JRTE, 43(3), 187-209.

Gao, X. (2020). Australian Students' Perceptions of the Challenges and Strategies for Learning Chinese Characters in Emergency Online Teaching. International Journal of Chinese Language Teaching, 1(1), 83-98. https://doi.org/10.46451/ijclt.2020.06.04

Gong, Y., Lai, C., \& Gao, X. (2020). The Teaching and Learning of Chinese as a Second or Foreign Language: The Current Situation and Future Directions. Front Educ China, 15, 1-13. https://doi.org/10.1007/s11516-020-0001-0

Hanban (2017). Hanban Confucius Institute annual development report. Confucius Institute Headquarters, Beijing (2017).

International Monetary Fund (2015, April). World economic outlook: uneven growth-shortand long-term factors. Washington, DC: International Monetary Fund.

Jiang, X. (2012). A critical review of research on strategies in learning Chinese as both a second and foreign language. Studies in Second Language Learning and Teaching, 2(1), 9-43. https://doi.org/10.14746/ssllt.2012.2.1.2

Jureynolds \& Ying, Y. (2020). Characteristics and Challenges of Chinese E-Learning Platforms in Indonesia. Journal of Physics: Conference Series, 1477, Education. https://doi.org/10.1088/1742-6596/1477/4/042014

Kuh, G. D. (March/April, 2003). What we are learning about student engagement from NSSE: Benchmarks for effective educational practices. Changes, 24-32.

Lewis, P. M., Simons, G. F., \& Fennig, C. D. (Eds.). (2015). Ethnologue: languages of the world (18th ed.). Dallas, TX: SIL International. Online version: Retrieved from http://www.ethnologue.com

Lew, Y. L. (2019). A Case Study on the Application of Cognitive Strategies to Malay Mandarin Learners. Jurnal Intelek, 15(1). Universiti Teknologi MARA, cawangan Perlis. Retrieved from https://jurnalintelek.uitm.edu.my/index.php/main/article/view/262

Loeb, S. (March 20, 2020). How Effective Is Online Learning? What the Research Does and Doesn't Tell Us. Retrieved from https://www.edweek.org/ew/articles/2020/03/23/how-effective-is-online-learning-what-t he.html

Lyu, B., \& Qi, X. D. (2020). A review of research on technology-assisted teaching and learning of Chinese as a second or foreign language from 2008 to 2018. Frontiers of Education in China, 15(1), 142-163. https://doi.org/10.1007/s11516-020-0006-8

Ma, X. L., Gong, Y., Gao, X. S., \& Xiang, Y. Q. (2017). The Teaching of Chinese as a second 
or foreign language: A systematic review of the literature 2005-2015. Journal of Multilingual and Multicultural Development, 38(9), 815-830.

Halliday, M. A. K. (2014). Notes on teaching Chinese to foreign learners. Journal of World Languages, 1(1), 1-6. http://doi.org. 10.1080/21698252.2014.893675.

Mok, S. S., Lau, S. K., \& Sankaran, S. (2019). The Error Analysis of Learning Mandarin Endocentric Phrases among the Malay Students in Malaysia. International Journal of Modern Languages and Applied Linguistics, 3(2), 49-62.

Moore, M. (1997). Theory of transactional distance. In D. Keegan (Ed.), Theoretical principles of distance education (pp. 22-38). New York: Routledge.

Martin, F., \& Bolliger, D. U. (2018). Engagement Matters: Student Perceptions on the Importance of Engagement Strategies in the Online Learning Environment. Online Learning Journal, 22(1), 205-222.

McLeod, S. A. (2018). Lev Vygotsky. Simply Psychology. Retrieved from https://www.simplypsychology.org/vygotsky.html

Moore, M. (1997). Theory of transactional distance. In D. Keegan (Ed.), Theoretical principles of distance education (pp. 22-38). New York: Routledge.

Moloney, R., \& Xu, H. (2015). Transitioning beliefs in teachers of Chinese as a foreign language: An Australian case study. Cogent Education, 2, 1-15. http://doi.org./10.1080/2331186X.2015.1024960

Perfetti, C. A., \& Dunlap, S. (2008). Learning to read: General principles and writing system variations. Learning to read across languages, 13-38. New York: Routledge.

Rahmat, N. H., Mok, S. S., Lau, S. K., \& Fan, P. S. (2020). Experiential Learning in Mandarin Classrooms: The Case for Simulation. International Journal of Asian Social Science, 10(4), 171-180.

Robinson, C. C., \& Hullinger, H. (2008). New benchmarks in higher education: Student engagement in online learning [Electronic version]. Journal of Education for Business, 84(2), 101-109.

Shen, H. H., \& Jiang, X. (2013). Character reading fluency, word segmentation accuracy, and reading comprehension in L2 Chinese. Reading in a Foreign Language, 25(1), 1-25.

Sung, K. (2014). Novice Learners' Chinese-Character Learning Strategies and Performance. Electronic Journal of Foreign Language Teaching, 11(1), 38-51.

Tseng, M. F., Lin, C. H., \& Chen, H. (2018). An immersive flipped classroom for learning Mandarin Chinese: design, implementation, and outcomes. Computer Assisted Language Learning, 31(7), 714-733.

Wang, W., \& Curdt-Christiansen, X. L. (2016). Teaching Chinese to international students in China: Political rhetoric and ground realities. Asia-Pacific Edu Res, 25, 723-734. 
https://doi.org/0.1007/s40299-016-0316-Z

Wang, S. (2013). Intermediate-Level Chinese Language Learners' Social Communication in Chinese on Facebook: A Mixed Methods Study. Graduate Theses and Dissertations. Retrieved from https://scholarcommons.usf.edu/etd/4606

Xu, H., Li, Y., \& Li, Y (2019). Using online applications to improve tone perception among 12 learners of Chinese. Journal of Technology and Chinese Language Teaching, 10(1), 26-56.

Yang, G., Xiang, H., \& Chun, L. (2018). CSL teachers' cognition in teaching intercultural $\begin{array}{llll}\text { communicative } \quad \text { competence. } & \text { 224-233. }\end{array}$ https://doi.org/10.1016/j.system.2018.09.009

Yang, J., Yin, C. X., \& Wang, W. (2018). Flipping the classroom in teaching Chinese as a foreign language. Language Learning \& Technology, 22(1), 16-26. https://dx.doi.org/10125/44575

Yi, Y., Xue, L., Mursitama, T. N., \& Yetty (2017). Mobile Learning Based of Mandarin for College Students: A Case Study of International Department'Sophomores. In 2017 11th International Conference on Information \& Communication Technology and System (ICTS).

Zhang, J. (1992). Modern Chinese character tutorial. Beijing: Modern Publishing House.

Zhang, C. (2020). From Face-to-Face to Screen-to-Screen: CFL Teachers' Beliefs about Digital Teaching Competence during the Pandemic. International Journal of Chinese Language Teaching, 1(1), 35-52. https://doi.org/10.46451/ijclt.2020.06.03

Zhao, L. X., Blankinship, B., Duan, Z., Huang, H., Sun, J., \& Bak, T. H. (2020). Comparing Face-to-face and Online Teaching of Written and Spoken Chinese to Adult Learners: An Edinburgh-Sheffield Case Study. International Journal of Chinese Language Teaching, 1(1), 83-98. https://doi.org/10.46451/ijclt.2020.06.05

Zheng, Y., \& Gao, A. X. (2016). Chinese humanities and social sciences scholars' language choices in international scholarly publishing. A ten-year survey, 48(1), 1-16. https://doi.org./ 10.3138/jsp.48.1.1

\section{Copyright Disclaimer}

Copyright for this article is retained by the author(s), with first publication rights granted to the journal.

This is an open-access article distributed under the terms and conditions of the Creative Commons Attribution license (http://creativecommons.org/licenses/by/3.0/). 